\title{
TEMPAT BUDAYA PINANGSIA
}

\author{
Kevin Wiranata ${ }^{1)}$, Lina Purnama, Dipl.Ing. ${ }^{2)}$
}

1) Program Studi S1 Arsitektur, Fakultas Teknik, Universitas Tarumanagara, kevinwiranata2101@gmail.com

2) Program Studi S1 Arsitektur, Fakultas Teknik, Universitas Tarumanagara, linapurnama.112@gmail.com

\begin{abstract}
Abstrak
Masa dimana kemajuan teknologi berkembang dengan pesat, gaya hidup masyarakat berubah ke arah serba instan. Walau teknologi memberikan kemudahan, namun di saat yang bersamaan mengubah pola pikir dan sikap masyarakat menjadi cenderung antisosial. Kurangnya interaksi ditambah dengan tuntutan kerja yang semakin tinggi di abad 21 dapat meningkatkan stress pada individu. Keberadaan wadah fisik untuk menunjang aktivitas sosial pun juga kurang. Gadget menciptakan sebuah ruang virtual untuk berkomunikasi namun tidak dapat mendekatkan pribadi secara langsung. Sejak zaman dahulu, budaya menjadi salah satu kegiatan yang membawa masyarakat atau komunitas dalam kebersamaan. Budaya adalah aktivitas yang dilakukan terus menerus secara rutin hingga menjadi sebuah kebiasaan kemudian menjadi karakter dari lingkungan tersebut. Aktivitas yang terjadi melahirkan ruang baik secara fisik maupun non-fisik yang dapat menunjang kebutuhan sosial masyarakat di dalamnya. Hingga saat ini, masyarakat di tengah pekerjaan masing-masing memiliki aktivitas selingan yang mereka lakukan untuk mencari hiburan di tengah kepenatan. Tempat Budaya Pinangsia adalah wadah untuk masyarakat saling berinteraksi sosial dengan berdasarkan pada aktivitas sehari-hari yang melibatkan seni dan budaya. Metode perancangan yang digunakan adalah bahasa pola. Program utama Tempat Budaya Pinangsia meliputi tempat makan dan bermain, tempat karaoke, workshop, dan common space untuk hangout, pengadaan acara, latihan fisik, dll. Tidak hanya terbatas untuk warga lokal, Tempat Budaya Pinangsia juga terbuka untuk pengunjung dari luar kawasan yang mencari kesenangan dan istirahat.
\end{abstract}

Kata kunci: budaya; interaksi; masyarakat; sosial

\begin{abstract}
An age where technology develop rapidly, the lifestyle of people began to shift to that of instantaneous gratification. Even though technology provides convenience and accessibility, at the same time it changes the mindset and behavior of the people into that of anti-social. The lack of interaction added up with high working demand in this $21^{\text {st }}$ century may increase an individual's stress levels. The existence of physical spaces to support social activity is undeniably minimal. Gadgets may create virtual spaces for people to communicate but they fail to make rapport between one individual and the other. Since the past decades, culture had been one of the activities which brought people and communities together. Culture defines activities which are done in routine thus becomes habits and eventually becomes the community's character. The occurring social activities gave birth to spaces either physical or non-physical which may support the social needs of the people. Up to this day, people tend to have third activities which they done to get rid of working exhaustion. Pinangsia Cultural Place is a place for people to socially interact with each other with the means of cultured daily activities. The method of design applied is pattern language. The main programs of Pinangsia Cultural Place include food court, karaoke, workshop, and common space for people to hangout, procuring event, physical exercises, etc. Not only does this tends to the needs of local community, Pinangsia Cultural Place is convivially open for outsiders who seek joy and rest.
\end{abstract}

Keywords: culture; interaction; people; social 


\section{PENDAHULUAN}

Dewasa ini, pertumbuhan kota modern seiring dengan perkembangan teknologi sangatlah cepat. Memasuki revolusi industri keempat, banyak kota-kota di dunia yang berkembang mengarah ke konsep smart city. Di satu sisi, kehadiran teknologi berdampak positif. Komunikasi dan pertukaran informasi menjadi lebih mudah tanpa dibatasi jarak maupun waktu. Namun di sisi lain, adanya teknologi membuat masyarakat kurang berinteraksi secara langsung sehingga melahirkan sikap yang anti-sosial dengan lingkungannya.

Kualitas kehidupan dalam kota tidak hanya terletak pada aspek ketersediaan infrastruktur namun juga kebiasaan (habit) masyarakat hidup sehari-hari. Di abad 21 ini tuntutan dunia kerja semakin tinggi. Banyak orang yang mengorbankan waktu untuk bekerja dengan minimnya waktu relaksasi. Waktu istirahat yang tersedia hanya saat pulang ke rumah sebelum keesokan harinya bekerja lagi, membentuk sebuah rutinitas tiada henti. Ditambah dengan keberadaan teknologi yang serba instan dapat beresiko pada kurangnya interaksi antar individu dan mengancam keberlanjutan sosial (social sustainability) di dalam lingkungan tersebut.

Jakarta merupakan salah satu kota yang berkembang pesat di dunia, lebih pesat dari Kuala Lumpur, Bangkok, maupun Beijing. Dengan pertumbuhan ekonomi yang besar, Jakarta dianggap salah satu alpha world city di dunia (Powell, 2000). Sebagai kota modern yang besar, pengaruh globalisasi juga terlihat jelas di Jakarta. Masyarakat dari berbagai kalangan usia sudah memiliki akses internet melalui teknologi gadget. Gadget berfungsi dari untuk tujuan edukatif hingga hiburan pribadi. Kehadiran teknologi ditengah rutinitas kerja tanpa henti menyebabkan kebiasaan hidup yang kurang sehat. Waktu untuk refleksi, relaksasi, dan berinteraksi sosial secara langsung semakin berkurang untuk setiap individu. Isu keberlanjutan sosial dalam kota pun menjadi sebuah masalah yang harus ditangani.

Keberadaan ruang ketiga (third place) menjadi wadah untuk individu dalam komunitas berinteraksi sosial sekaligus menggambarkan pengalaman personal. Third place hadir di antara tempat tinggal (first place) dan tempat kerja (second place). Di sejarah peradaban manusia, third place selalu ada di berbagai zaman yang berfungsi sebagai tempat untuk masyarakat lokal berkumpul dan bersosialisasi. Keberadaan ruang ketiga penting untuk pertumbuhan dan pematangan suatu kawasan dan masyarakat di dalamnya. Tanpa kehadiran ruang ketiga, kawasan perkotaan gagal untuk menjalin aneka ragam hubungan antar individu yang menjadi esensi dalam kehidupan perkotaan. Individu akan merasakan kesepian, ditambah dengan teknologi yang tidak berhenti berkembang hanya membuat interaksi sosial antar individu semakin terpisah (Oldenburg, 1989).

Pinangsia, Glodok adalah kawasan yang memiliki budaya dan sejarah panjang sejak dari masa kolonial Belanda di Batavia, dan tidak lepas dari keberadaan etnis Tionghoa yang menjadi penduduk utama di dalamnya. Pasca kejadian Chinezenmoord di tahun 1740, pemukiman kaum Tionghoa dipindahkan ke Glodok, dan sejak saat itu menjadi pusat kehidupan bekerja dan berbudaya masyarakat Tionghoa (Utama, 2007). Sebagai kaum minoritas yang datang dari negeri luar, masyarakat Tionghoa membutuhkan upaya untuk dapat bertahan hidup di negeri yang baru, terutama dengan cara berdagang. Kawasan Pinangsia dan Glodok yang menjadi tempat tinggal mereka yang baru juga berperan sebagai tempat dimana mereka bekerja sehingga terjadi kawasan integrasi antara huni dan kerja. Di tengah tuntutan kerja yang tinggi, mereka membutuhkan aktivitas selingan untuk menjadi hiburan. Aktivitas selingan ini menjadi kebiasaan atau budaya mereka.

Batasan masalah dalam proyek ini, pertama program yang ditawarkan berbasis komunitas sehingga hanya menganalisa kebutuhan dari masyarakat sekitar Pinangsia. Kedua, cakupan kawasan yang dianalisa adalah dalam radius $1 \mathrm{~km}$ dari tapak. Ketiga, program yang dipilih berada di antara kategori commercial, hospitality, dan entertainment. Terakhir, program bersifat kontekstual dengan kawasan dalam aspek keadaan sosio-ekonomi, aktivitas masyarakat, sejarah dan budaya. Rumusah masalah utama yaitu "apa yang dibutuhkan kawasan Pinangsia dan sekitarnya untuk menunjang keberlanjutan sosial dalam masyarakat?", sehingga proyek bertujuan untuk menyediakan wadah bagi komunitas masyarakat berinteraksi sosial dan menyediakan sarana hiburan dengan budaya sebagai media perantara. 


\section{KAJIAN LITERATUR \\ Space and Place}

Konsep space adalah sebuah ruang yang dapat ditempati dan menjadi wadah untuk aktivitas manusia, sedangkan place merupakan bagian dari space yang disertai dengan makna dan nilai tersendiri. Interaksi antar manusia dan lingkungan yang membedakan karakteristik place dan space. Sebuah place adalah tempat yang memiliki nilai yang dirasakan, umumnya berhubungan dengan keamanan dan stabilitas. Jikalau sebuah space menciptakan pergerakan, maka place memberikan sebuah stop/pause (Madanipour, 1996).

\section{A Sense of Place}

Setiap kawasan memiliki sense of place masing-masing yang unik. Namun banyak kawasan yang telah kehilangan identitasnya dan menyebabkan masyarakat di dalamnya turut kehilangan identitas "rumah" mereka. Tidak sebatas masalah cultural shock ataupun shock of the new namun perasaan yang mendalam yang tidak dapat menerima apa yang terbangun. Kawasan yang baru menjadi tidak kontekstual dan tidak natural (Lang, 2005).

Sense of place memiliki dua aspek utama yang menjadi pertimbangan; pertama aspek sosiologis dan kedua aspek psikologis. Aspek sosiologis berpengaruh terhadap kesadaran akan suatu tempat milik suatu komunitas sedangkan aspek psikologis berpengaruh terhadap rasa kepemilikan terhadap suatu kawasan dan budaya di dalamnya. Kehilangan identitas yang dirasakan masyarakat disebabkan oleh perubahan yang terjadi terhadap kedua dimensi diatas (Lang, 2005). Banyak property developer di dunia yang hanya mengejar ambisi mereka untuk memperoleh keuntungan sebesar-besarnya, melupakan konteks lokal dan tradisi yang telah ada sejak lama. Perencanaan kawasan yang baru menjadi cerminan terhadap self-pride mereka yang ingin memamerkan kekayaan dan kemajuan kepada masyarakat global. Wajah arsitektur menjadi sama rata dan kehilangan keunikan masing-masing. Beberapa berupaya dengan konsep glocal, yaitu gaya internasional namun menerapkan referensi lokal dalam penampilan; tetapi tetap tidak memperhatikan kondisi lokal dan gaya hidup maupun tradisi bagaimana bangunan bertemu dengan jalan untuk menciptakan suatu place. Perencanaan seperti ini telah terjadi dan sedang berlangsung di berbagai penjuru dunia, misalnya Lujiazui di Shanghai, False Creek dan Concord Pacific Plaza di Vancouver, Kanada yang sama. Begitu pula Rinkai FunuToshin di Tokyo, Jepang, maupun di Canary Wharf, London yang terkenal (Lang, 2005).

\section{Kota: Wadah yang Menyatukan}

Kota selalu berkembang dari zaman ke zaman seiring peradaban manusia. Sebuah kota berperan sebagai tempat atau wadah di mana masyarakat dapat saling berinteraksi dan beraktivitas untuk memenuhi kebutuhan esensial hidup sehari-hari. Kota yang baik adalah kota yang dapat menunjang seluruh aspek kebutuhan masyarakat di dalamnya.

Paradigma kota modern adalah sebagai pusat konsumsi dibandingkan dengan produksi. Upaya pemerintah untuk dapat mengawasi dan meregulasi kehidupan dalam kota selayaknya sebuah mesin menghancurkan tradisi dan melahirkan suburbia (Powell, 2000) secara cepat dan tidak terkendali. Di satu sisi, sebuah kota yang dapat mewadahi keberlanjutan hidup masyarakatnya secara ekonomi dan finansial adalah contoh kota yang baik. Namun keberadaan dan makna kota yang hanya sebatas untuk menjalankan politik dan ekonomi menjadi tantangan terhadap stabilitas sosial, bahkan dapat mengancam ketahanan hidup manusia di dalamnya. Sebuah paradigma baru dibutuhkan untuk mengubah konsepsi terhadap kota modern. Kota yang baru harus dapat menunjang interaksi antar estetika, politik, dan ekonomi dalam kesetaraan. Kota bukanlah suatu tempat sebatas untuk menghasilkan uang, namun juga untuk menunjang kenikmatan hidup; bukanlah suatu ruang hanya untuk ditinggali, namun suatu ruang yang berjiwa. Hal ini dapat diusahakan dengan penerimaan keberagaman yang menjadi karakteristik baru dalam kota. Kota yang baru bertujuan agar masyarakat yang hidup di dalamnya dapat merasakan kebebasan, berkecukupan, dan kebahagiaan. Aktivitas yang beragam antara menghuni, bekerja, rekreasi, dan sebagainya dalam satu kawasan terintegrasi, menciptakan pengalaman ruang yang mempengaruhi hidup masyarakat di dalamnya secara psikologis. 
Kota sebagai wadah manusia harus dapat melahirkan rasa kepemilikan (sense of belonging). Sandel menyatakan "Dari institusi publik kita, seperti perpustakaan umum, transportasi umum, taman, dan pusat rekreasi; berperan untuk mereka yang tidak mampu menunjang pelayanan semacamnya oleh diri mereka sendiri. Tempat-tempat itu adalah lokasi untuk mengembangkan rasa kepemilikan, sehingga orang dari berbagai latar belakang dapat saling berinteraksi dan berbagi nilai-nilai yang sama rata." Ruang publik kota saat ini dimanfaatkan untuk keamanan, pertahanan, dan kemungkinan. Keamanan dapat terlihat dari perbedaan ruang inklusif dan eksklusif. Ruang yang inklusif adalah ruang yang terbuka untuk semua kalangan dan memaksimalkan aktivitas di ruang publik. Ruang eksklusif sebaliknya adalah ruang yang tertutup, terbatas, dan berpotensi untuk melahirkan kejahatan (McLaren \& Agyeman, 2015).

\section{Third Place}

Contoh yang ditetapkan oleh lingkungan yang telah menyelesaikan masalah place dan yang ditetapkan oleh pemukiman kecil menyatakan bahwa agar kehidupan sehari-hari dapat rileks dan memenuhi kebutuhan, haruslah menemukan keseimbangan di tiga aspek pengalaman ruang. Yang pertama ialah domestik, kedua ialah produktif, dan ketiga adalah inklusif secara sosial. Setiap aspek pengalaman ini dibangun atas dasar asosiasi dan hubungan yang berhubungan; masing-masing memiliki tempat atau ruang fisik yang berbeda dari lainnya. Apa yang kota secara general gagal untuk menunjukkan adalah aspek ketiga yang berbeda dari rumah dan tempat kerja. Kehidupan publik informal terasa tidak terbentuk dan tidak teratur, padahal harusnya lebih difokuskan. Disaat permasalahan place telah diselesaikan, maka kebutuhan sehari-hari akan kehidupan publik informal masyarakat dapat terpenuhi (Oldenburg, 1989).

Third place adalah solusi untuk memenuhi kebutuhan akan kehidupan publik informal tersebut. Third place adalah wadah untuk aneka ragam ruang publik yang menunjang perkumpulan masyarakat di luar tempat tinggal dan tempat kerja. Third place bersifat simpel dan netral. Di setiap kota atau negara memiliki jenis third place yang berbeda-beda sesuai dengan sejarah dan budaya setempat. Mereka tidak menonjol atau terkesan grandeur, namun bersifat lokal dan reguler. Sebuah third place harus netral dalam arti ramah oleh semua kalangan masyarakat, menunjang interaksi sosial, mudah diakses, secara reguler dikunjungi, simple dan kontekstual serta terkesan fun \& playful secara psikologis (Oldenburg, 1989). Sebagai ruang yang bersifat reguler dan menjadi wadah aktivitas setiap harinya (everyday space), third place adalah tempat dimana pengalaman dan ekspresi politik bergabung; dan di luar dari lingkaran desain profesional. Tidak seperti ruang publik pada umumnya yang normatif dan menciptakan ideologi eksisting, third place hadir untuk menjungkirbalikkan status quo. Ruang-ruang ini lahir secara fisik di antara lingkup privat, komersil, dan domestik, serta mengandung makna yang lebih dari satu dan selalu berubah tergantung dari masyarakat yang menggunakan dan mengartikannya. Akhirnya third place merupakan ruang representasi, memegang berbagai makna yang teraktivasi melalui interaksi sosial (Crawford, 2008).

\section{Ruang Berbasis Komunitas}

Lingkungan hidup masyarakat saat ini dikelilingi oleh teknologi dan komputerisasi, yang menyebabkan sifat perkotaan menjadi konsumtif dan anti-sosial. Masalah tersebut dapat diatasi dengan pembentukan dan pengelompokan komunitas melalui ruang, nilai ketertarikan, zaman dan spiritualitas (Zamfir, 2015).

Latar belakang sosio-kultural memiliki beragam sudut pandang. Hubungan antar budaya dan komunikasi adalah sebuah kekuatan menurut penelitian ahli-ahli terhadap kondisi masyarakat saat ini. Budaya dengan nilai artistik dan saintifik, masuk ke dalam kehidupan sosial masyarakat hingga meluas. Konteks ruang arsitektur yang berbasis komunitas bersifat integratif dan berpola budaya - komunikasi - komunitas - zaman (Zamfir, 2015). Ruang komunitas berarti lingkungan terbangun harus dapat menawarkan dirinya untuk partisipasi 
komunitas secara inklusif. Masyarakat membutuhkan konsep ruang berbasis komunitas yang direncanakan untuk dapat;

- Menjawab kebutuhan kontemporer.

- Menciptakan arsitektur yang sepenuhnya melayani komunitas.

- Menyadari kebutuhan pendekatan interdisiplin dalam komunitas.

- Melahirkan komunitas berjiwa self-sufficient.

Kehidupan sosial saat ini dipenuhi dengan warna konsumerisme dan spektakularisme, yang menggoyahkan nilai lokal komunitas. Pola hidup modern mengembangkan nilai egois, individualis, konsumtif, persaingan negatif, dll. Di sisi lain, waktu kosong hampir non-existent atau bertempat di virtual yang mengancam keberadaan interaksi sosial dalam realita konkret (Zamfir, 2015). Kehadiran ruang berbasis komunitas bertujuan untuk mencegah masalah tersebut dan mengembalikan nilai identitas suatu kawasan.

\section{Komunitas Chinatown Art Culture}

Pendirian komunitas ini di latar belakangi oleh eksistensi kebudayaan Betawi dan Tiongkok yang berakulturasi baik dari segi makanan, seni, maupun bahasa. Komunitas sosial kemasyarakatan ini hadir sebagai perkumpulan warga yang peduli akan nilai seni dan budaya di kawasan Pecinan, tanpa membedakan etnis, keturunan dan agama. Cita-cita komunitas berupa persatuan keragaman budaya (Erwan, 2018).

Kebudayaan lokal adalah sesuatu yang dilestarikan dan diturunkan sehingga nilainya akan bertahan. Selain dari melestarikan budaya, Chinatown Art Culture juga rutin mengadakan berbagai kegiatan sosial dan pendekatan ke masyarakat yang membutuhkan. Pengembangan seni budaya berperan pula untuk mendukung perkembangan ekonomi kreatif bagi masyarakat (Erwan, 2018).

\section{Fasilitas Food Court}

Food court bertujuan untuk menyediakan fasilitas makan dan minum untuk kuantitas pengunjung yang tinggi. Faktor desain sebuah food court yang fungsional meliputi berbagai aspek seperti berikut (G.Mion, 2017);

- Jumlah pengunjung dilayani

- Jadwal dan durasi makan

- Pembayaran

- Pengantaran makanan dan metodologi makan

- Fungsi tambahan lainnya yang spesifik

Cara pembayaran terbagi menjadi 3 (tiga) opsi yaitu gaya kafetaria, a la carte, dan langsung. Food court memiliki beberapa tipe dan organisasi ruang sebagai berikut; lobby, tempat antri, serving area, kasir, area makan, dapur dan area persiapan, area cuci, gudang, dan loading dock.

\section{Fasilitas Karaoke}

Karaoke adalah bentuk hiburan interaktif dimana penyanyi bernyanyi bersama dengan rekaman musik menggunakan microphone dan sound system. Karaoke adalah tempat berinteraksi sosial yang memiliki beberapa peran sebagai berikut (Bina Nusantara University, 2014);

- Sarana interaksi antara pihak satu dengan lainnya

- Forum untuk kelompok/individu

- Meningkatkan suasana yang lebih baik dalam sebuah kelompok

- Sarana menghilangkan stress

- Sarana berkomunikasi, mengisi waktu luang dsb.

- Sarana berlatih menyanyi 
Standar ruang karaoke sesuai lampiran Peraturan Menteri Pariwisata dan Ekonomi Kreatif Republik Indonesia No. 16 Tahun 2014 tentang Standar Usaha Karaoke (Sudjawardi, 2017);

- Ruang menyanyi: luas ruangan paling kecil 2.5×3.5 meter, penyejuk udara dan exhaust fan, tempat duduk dan meja, kaca kontrol dipasang di pintu masuk, kedap suara dan sistem serta perangkat tata suara, daftar lagu, layer monitor.

- Fasilitas penunjang: tempat pembayaran, tempat penjualan makanan dan minuman ringan, ruang tunggu pengunjung, toilet bersih terawat dan terpisah untuk pria dan wanita, lift/escalator untuk diatas lantai 4.

\section{Cultural Workshop}

Fasilitas workshop untuk pelatihan mencakup beberapa jenis ruang kelas untuk memenuhi kebutuhan dari pengguna di dalamnya baik anak hingga dewasa seperti berikut (National Institute of Building Sciences, 2017);

- Auditorium, ruang conference, ruang seminar, ruang audio/visual, ruang computer

- Ruang kelas yang baik memiliki fleksibilitas yang baik. Dalam ruang kelas, fleksibilitas dapat dinilai dari (National Institute of Building Sciences, 2017);

- Kluster antar area murid mengelilingi pusat dimana pelatih memberi instruksi.

- Penggunaan furnitur modular atau portable sehingga mudah dirapikan.

- Penyusunan ruang sesuai tujuan program edukasi.

- Konektivitas ruang, keterbukaan visual, dan privasi akustik.

Sebuah ruangan kelas wajib memiliki indoor quality yang baik guna menunjang aktivitas di dalamnya. Beberapa aspek yang dipertimbangkan dalam perancangan kelas workshop adalah (National Institute of Building Sciences, 2017); kualitas akustik, pencahayaan optimal, daylighting, material ramah lingkungan, jarak pandang baik, estetika, kenyamanan termal dan sirkulasi udara.

\section{Cultural Market, Plaza, Amphitheater}

Hal terpenting yang wajib dipertimbangkan dalam perancangan plaza dan ruang public ialah potensi pemakaian ruang tersebut kedepannya. Plaza harus dapat menunjang ragam aktivitas baik pasif maupun aktif, formal maupun informal, kelompok maupun pribadi. Karakteristik yang ada di plaza termasuk (Greenbaum, 2016);

- Aksesibilitas terhadap fitur/amenitas dan rute sirkulasi yang disesuaikan dengan lanskap sekitarnya

- Menggunakan material, furnitur, signage yang baik dan jelas.

- Penggunaan elemen air atau sculpture menjadi opsi untuk meningkatkan estetika.

- Perawatan yang rendah biaya.

- Fleksibilitas melalui pencahayaan dan infrastruktur sederhana.

- Furnitur outdoor yang lengkap.

- Dapat dimanfaatkan untuk program atau event lainnya.

- Menunjang aktivitas yang beragam sehingga tidak membosankan.'

Program plaza diintegrasikan dengan cultural market di manahasil karya dari workshop dipamerkan dan dijual untuk menunjang perkembangan ekonomi kreatif. Aktivitas di plaza juga terintegrasi dengan amphitheater yang menjadi tempat baik individu maupun kelompok melakukan aktivitas seperti; hangout, latihan fisik (senam, tarian, bela diri, dll), pertunjukan/festival. Ruang publik saling terintegrasi secara aktivitas dan sirkulasi membuat ruang tersebut menjadi sebuah common space yang bernilai untuk individu/kelompok di dalamnya. 


\section{METODE}

\section{Metode Pengumpulan Data}

1. Observasi

Pengamatan langsung tapak dan kawasan sekitar di Pinangsia, Tamansari, Jakarta Barat.

2. Studi literatur

Mempelajari teori mengenai karakteristik third place, kebutuhan akan keberlanjutan sosial, serta sejarah \& budaya dari kawasan dan masyarakat di dalamnya.

\section{Metode Analisis Data}

1. Data Kuantitatif

Berikut analisa kuantitatif yang digunakan untuk menentukan tapak perancangan; mapping kegiatan, pusat-pusat aktivitas, titik transportasi umum, klasifikasi jalan, jalur hijau, ruang terbuka hijau \& ruang terbuka biru, peraturan zonasi, data demografi kawasan, dan intensitas lahan.

2. Data Kualitatif

Berikut analisa kualitatif yang digunakan untuk mempelajari karakter dan nilai identitas kawasan; sejarah Pecinan dan Glodok, budaya masyarakat Tionghoa dan hubungannya dengan etnis lain, pola hidup masyarakat di kawasan pada masa lampau.

\section{Metode Perancangan}

Metode yang diaplikasikan pada perancangan Pinangsia Cultural Place adalah bahasa pola (pattern language) yang diadopsi dari karya Christopher Alexander. Bahasa pola mempelajari pola-pola yang membuat suasana hidup dan dengan mengikuti pola tersebut, disrupsi dapat dihindari (Tjahjono, 2000).

\section{Pola}

Pola mengacu pada sesuatu yang susunannya beraturan, menjadi dasar untuk repetisi, dan mengandung peristiwa. Pola dapat diamati dengan mengunjungi tempat yang pernah dialaminya berulang kali atau dapat ditemukan melalui kesamaan perasaan yang dialami bersama oleh sejumlah rekan atas suatu tempat.. Unsur-unsur fisik yang ditemukan dalam tempat tersebut membentuk peristiwa yang berlangsung dan saling berhubungan satu dengan lainnya sehingga membentuk suatu konteks (Tjahjono, 2000).

\section{Bahasa Pola}

Pola memiliki bahasa yang terdiri atas pola-pola. Seperti bahasa memiliki tata bahasa (grammar) yang mengatur kata-kata menjadi susunan bermakna, bahasa pola memiliki susunan yang mengatur pola-pola menjadi pola bermakna. Bahasa pola bertujuan untuk menyusun pola-pola yang ada menjadi sebuah "kalimat" yang dapat dimengerti. Unsur-unsur dalam pola membentuknya menjadi kaidah yang utuh. Tidak ada pola yang terlepas dari pola lain yang lebih besar darinya atau yang lebih kecil darinya, sehingga diperlukan pengamatan dalam konteks yang lebih besar (Tjahjono, 2000).

Pola yang baik adalah pola yang dapat menyelesaikan konflik yang terjadi dalam konteks perancangan, mengandung suatu konteks, masalah, dan solusi. Penyelesaian yang mengandalkan bahasa pola menyerupai suatu proses pembelahan terus menerus hingga menghasilkan suatu produk baru yang seutuhnya berbeda/unik. 


\section{DISKUSI DAN HASIL}

\section{Analisa Kawasan}

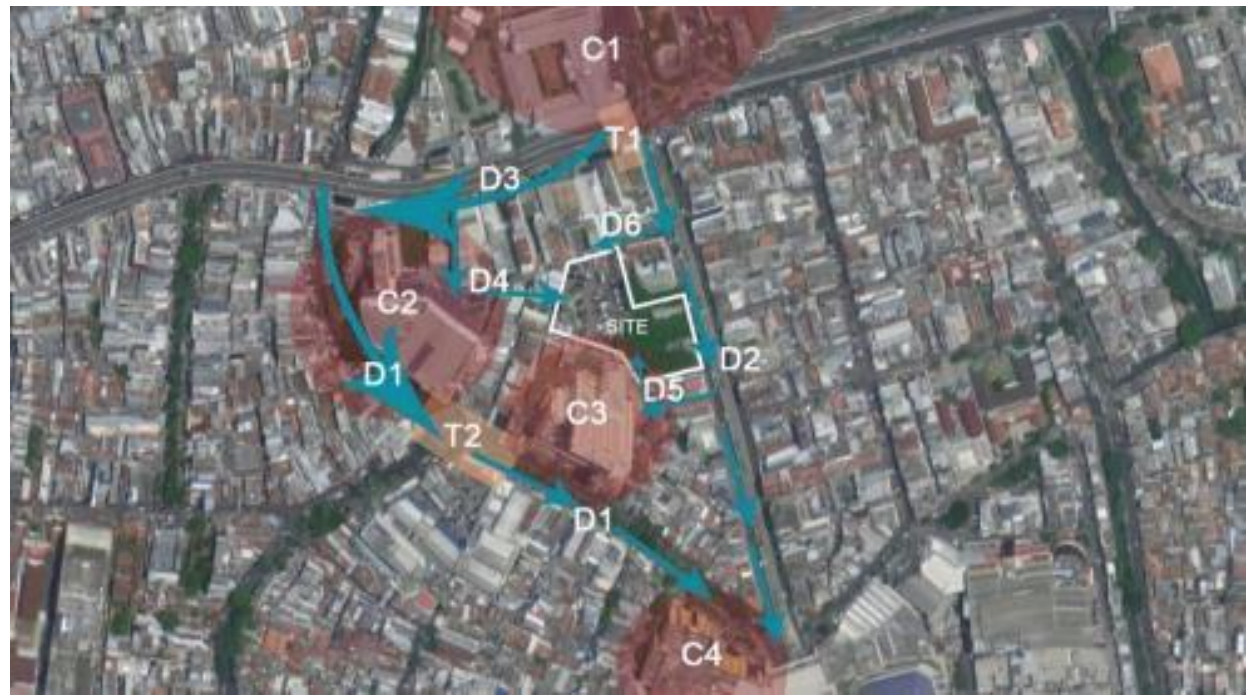

Gambar 1. CDTA Mapping

Sumber: Penulis,2019

\section{Identifikasi Center}

Tablel 1. Identifikasi Center

\begin{tabular}{lll}
\hline Kode & Nama Tempat & Fungsi/Aktivitas \\
\hline C1 & Stasiun Jakarta Kota & Transit, Commute, Hangout \\
\hline C2 & Pasar Pagi Asemka & Pusat Belanja Grosir \\
\hline C3 & Pancoran Chinatown Point & Pusat Belanja, Residential Apartment \\
\hline C4 & Pasar Jaya Glodok & Pusat Belanja Elektronik \\
\hline
\end{tabular}

Sumber: Sumber: Penulis,2019

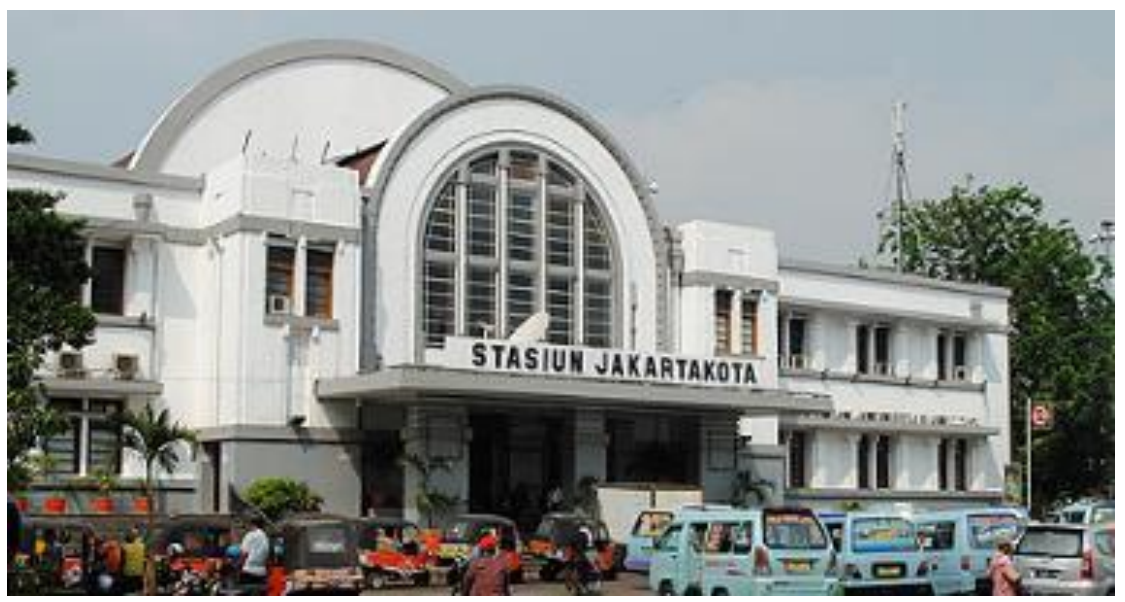

Gambar 2. Stasiun Jakarta Kota Sumber: google.com

C1 - Stasiun Jakarta Kota adalah titik pemberhentian pusat dari moda transpo 
rtasi umum di Jakarta (KRL dan Transjakarta). St. Jakarta Kota memiliki kafe untuk hangout, dan underpass yang menjadi ruang publik terbuka untuk dinikmati pengunjung. Ditambah dengan adanya jejeran pedagang yang jual makanan ringan dan pakaian. St. Jakarta Kota berpotensi menjadi akses utama untuk orang dari luar kawasan Taman Sari yang ingin berkunjung ke tapak.

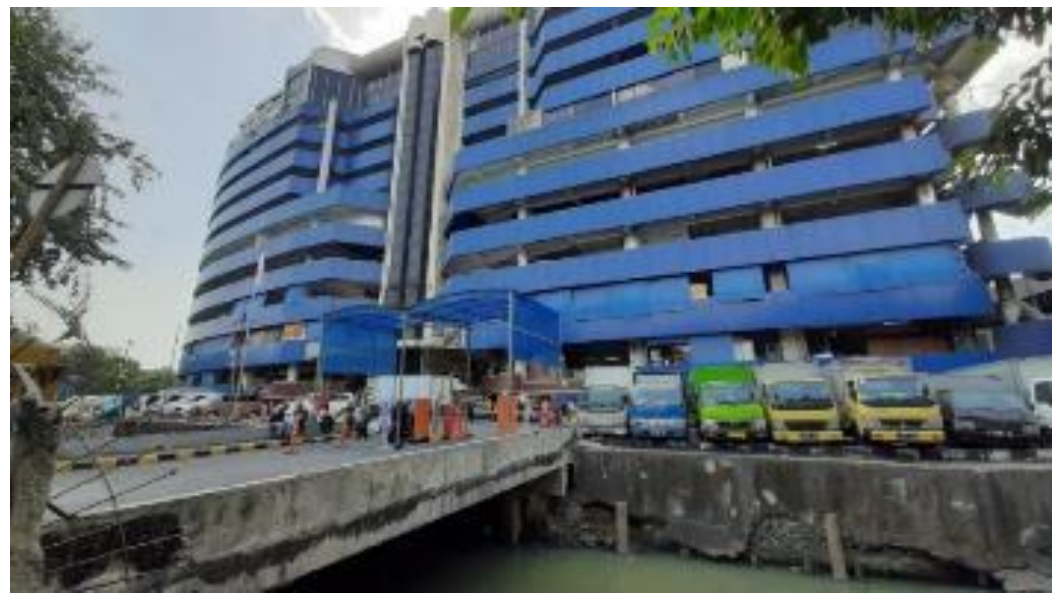

Gambar 3. Pasar Pagi Asemka

Sumber: Penulis,2019

C2 - Pasar Pagi Asemka adalah pusat perbelanjaan grosir untuk barang-barang seperti mainan anak. Sejak pagi dari pukul 07.00 sudah banyak orang beraktivitas; pemborong yang memesan barang, penjual yang menjual barang dagangan, dan kuli yang mengangkut barang bolak-balik dari toko ke pick-up dan sebaliknya. Selain itu di pinggir jalanan terdapat gerobak-gerobak makanan dan minuman jalanan untuk mereka nikmati di tengah pekerjaan berat.
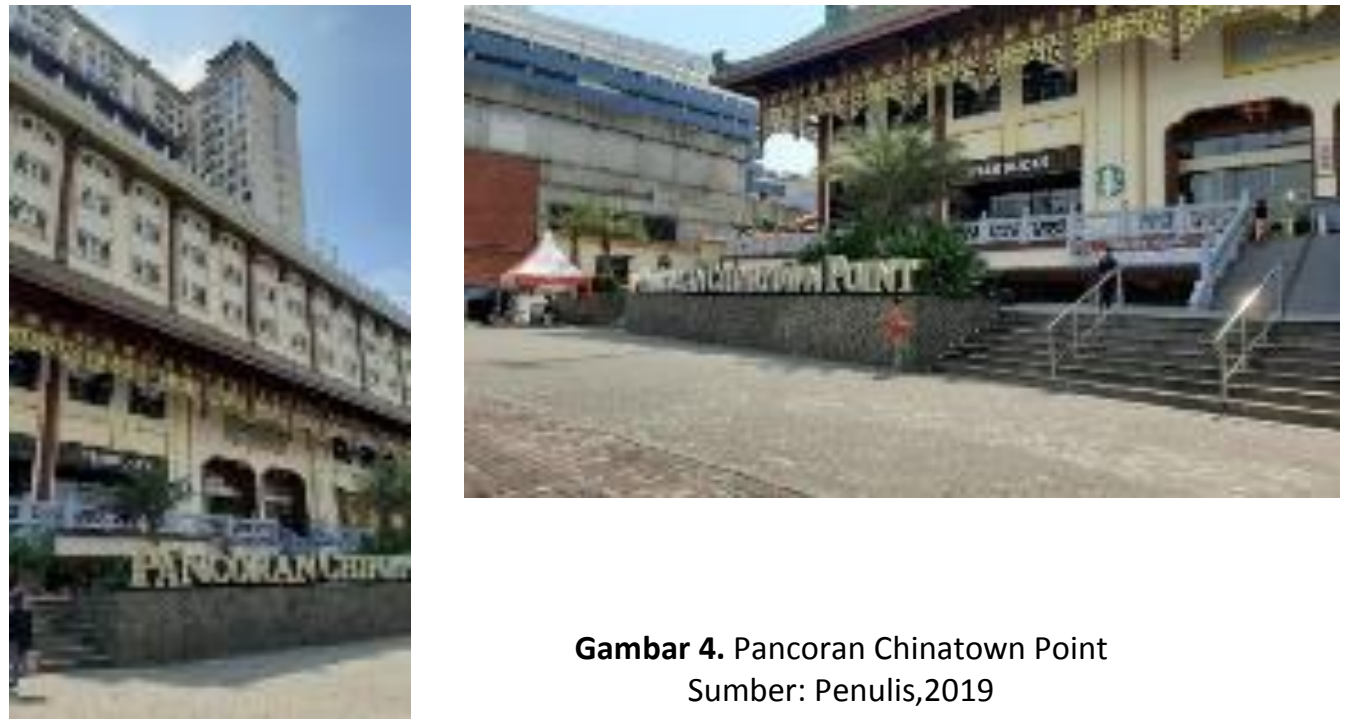

Gambar 4. Pancoran Chinatown Point Sumber: Penulis,2019

C3 - Pancoran Chinatown Point adalah shopping mall yang dilengkapi dengan apartemen residensial. Saat ini masih tergolong baru dan belum banyak toko yang buka, namun berpotensi menjadi pusat kegiatan belanja yang ramai di beberapa tahun yang akan mendatang. Di depan PCP terletak sebuah ruang publik terbuka yang dapat digunakan untuk orang lewat duduk-duduk hangout. 


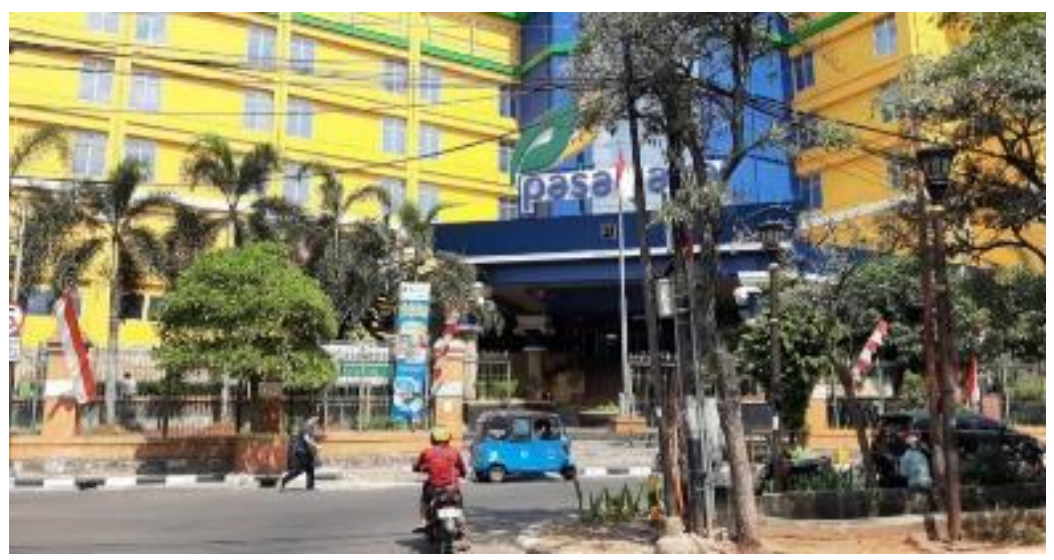

Gambar 5. Pasar Jaya Glodok

Sumber: Penulis,2019

C4 - Pasar Jaya Glodok adalah perusahaan daerah milik pemerintah Provinsi DKI Jakarta yang melaksanakan pelayanan umum dalam bidang pengelolaan area pasar, dan pembinaan pedagang. Di Glodok sendiri menjadi pusat penjualan barang elektronik. Di depan Pasar Jaya terdapat titik temp angkot dan pangkalan ojek online. Hal ini membuat area menjadi salah satu titik dengan frekuensi perpindahan orang yang cukup tinggi. Angkot yang lewat adalah M08 dan M12 dengan frekuensi 3-4 angkot per menit.

\section{Identifikasi Direction}

Tablel 2. Identifikasi Direction

\begin{tabular}{lll}
\hline Kode & Nama Tempat & Fungsi/Aktivitas \\
\hline D1 & Jl. Pintu Kecil - Pancoran & Pertokoan, food street, temp bajaj \\
\hline D2 & Jl. Pintu Besar Selatan & Street artists, pedestrian teduh \\
\hline D3 & Jl. Pintu Besar Selatan 1 & Pertokoan \\
\hline D4 & Gg. Pintu Besar Selatan 1 & Food street \\
\hline D5 & Gg. Pintu Besar Selatan 2 & Food street \\
\hline D6 & Gg. Pintu Besar Selatan 1 & Entrance/Exit Parking \\
\hline
\end{tabular}

Sumber: Penulis,2019
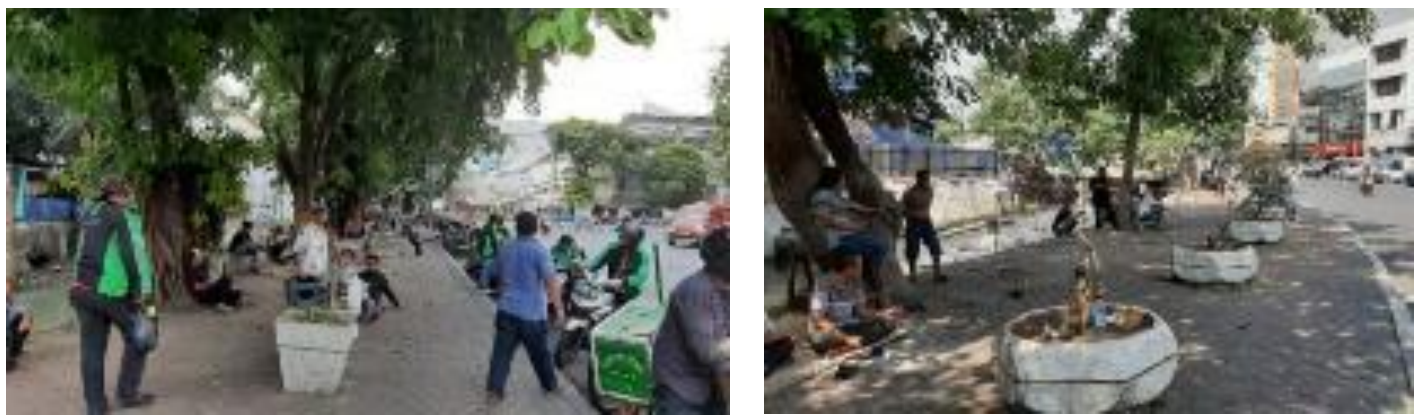

Gambar 6. Trotoar Depan Asemka Sumber: Penulis,2019 
D1 - Jl. Pintu Kecil-Pancoran adalah jalan yang menghubungkan Jl. Pintu Besar Selatan 1 dengan JI. Pintu Besar Selatan. Di jalan ini terdapat deretan mobil parkir untuk loading barang, gerobak-gerobak jajanan, dan pertokoan obat. Jalur pedestrian yang terdapat di Jl. Pintu Kecil, depan Kali Krukut selebar 4,5 meter dan menjadi tempat banyak kuli dan pedagang pinggiran nongkrong minum kopi/tiduran.
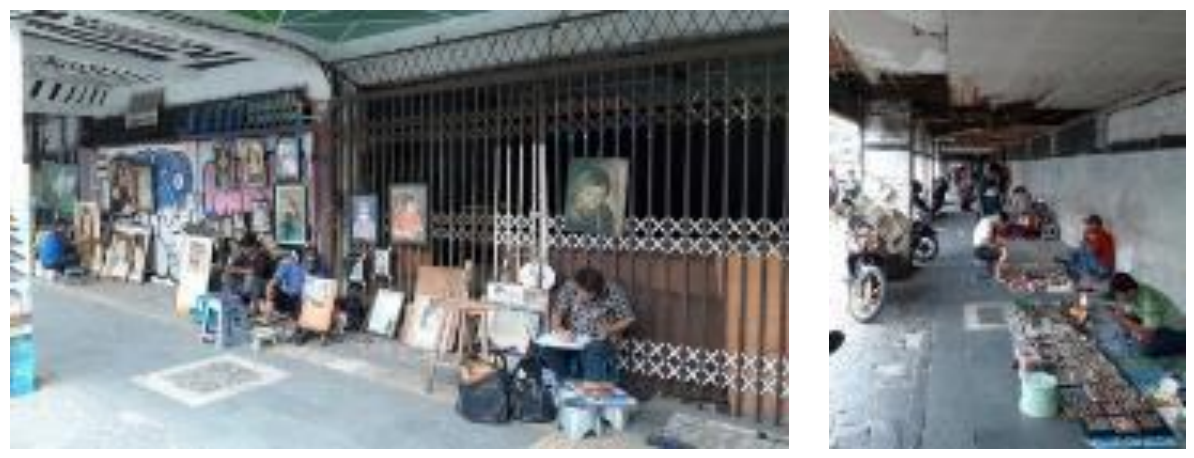

Gambar 7. Pedagang dan pelukis di Jl. Pintu Besar Selatan Sumber: Penulis,2019

D2 - Jl. Pintu Besar Selatan adalah jalan utama dalam kawasan, yang menghubungkan Kota Tua hingga Gajah Mada. Jalan ini menjadi potensi untuk keluar/masuk kendaraan ke tapak karena frekuensi kendaraan yang lewat tinggi. Di jalan ini terletak terminal bayangan Pasar Glodok dan Jembatan Glodok di seberang Pasar Jaya, dilewati angkot M08 (Tanah Abang-Kota) \& M12 (Ps. Senen-Kota). Di pedestrian jalan ini dipayungi oleh kehadiran arcade ruko-ruko, dan dimanfaatkan oleh pelukis jalanan untuk menjual dagangan.

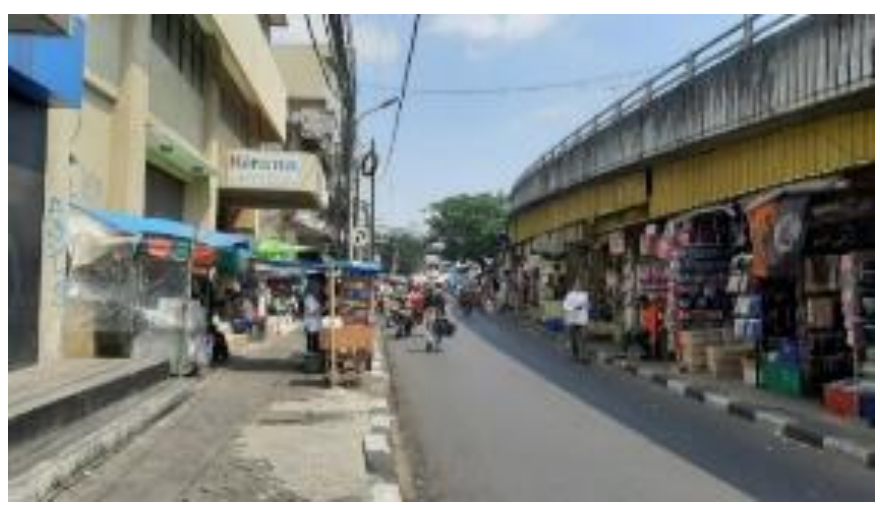

Gambar 8. Jl. Pintu Besar Selatan 1

Sumber: Penulis,2019

D3 - Jl. Pintu Besar Selatan 1 adalah jalan selebar 3,5 meter disamping flyover Pasar Pagi. Di deretan jalan ini terletak pertokoan yang menjual dekorasi/ornament rumah dan peralatan sekolah. Hanya dapat dilalui 1 mobil dan 1 motor. Jalan ini yang menghubungkan Kota Tua dengan Pasar Pagi.

D4 - Gang Pintu Besar Selatan 1 adalah gang kecil yang berderetan penjual makanan/minuman pinggiran, hanya dapat dilewati oleh pejalan kaki dan pengendara motor Jalan ini menghubungkan Jl. Pintu Besar Selatan 1 dengan tapak. 

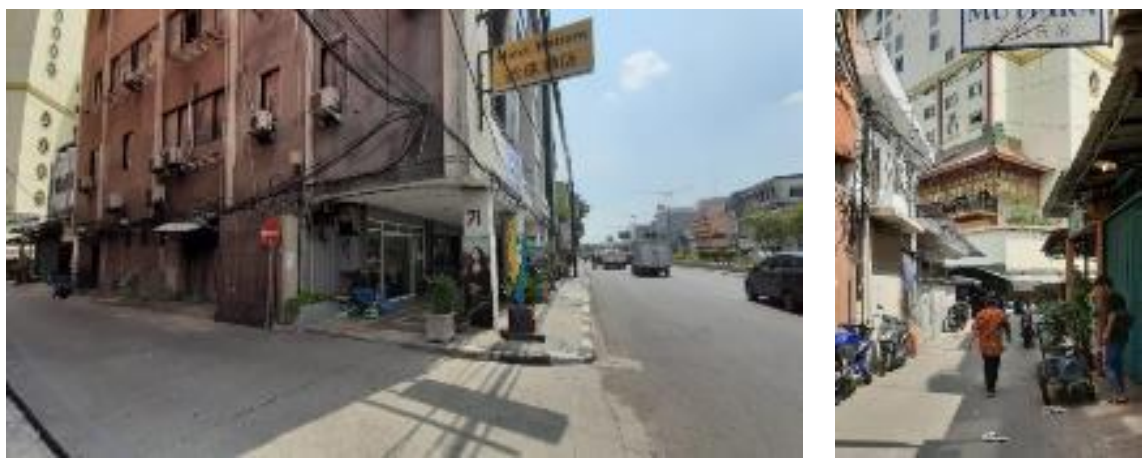

Gambar 9. Gang Pintu Besar Selatan 2 Sumber: Penulis,2019

D5 - Gang Pintu Besar Selatan 2 adalah jalan kecil selebar 3,5 meter dari Jl. Pintu Besar Selatan. Menjadi jalur exit dari mobil/motor yang parkir di tapak. Di jalan ini bersuasana teduh karena terlindungi oleh tinggi bangunan diantaranya. Terdapat beberapa warung makanan di pinggir jalan.

D6 - Gang Pintu Besar Selatan 1 adalah jalan kecil yang khusus digunakan untuk masuk/keluar kendaraan yang parkir di area tapak. Jalan ini terhubung dengan Jl. Pintu Besar Selatan. Di deretan jalan ini terdapat ruko-ruko yang menjual barang seperti perhiasan.

Identifikasi Transition

Tablel 3. Identifikasi Transition

\begin{tabular}{lll}
\hline Kode & Nama Tempat & Fungsi/Aktivitas \\
\hline T1 & Zebra Cross & Prasarana penyeberangan \\
\hline T2 & Pertigaan Asemka & Jembatan Intersection, penyeberangan \\
\hline
\end{tabular}

Sumber: Penulis,2019

T1 - Zebra Cross terletak di Jl. Jemb. Batu yang menjadi fasilitas menyeberang pengunjung Kota Tua ke Pasar Pagi dan sebaliknya. Keberadaan zebra cross menjadi akses yang mudah untuk menyatukan wisata Kota Tua dengan pusat perbelanjaan.

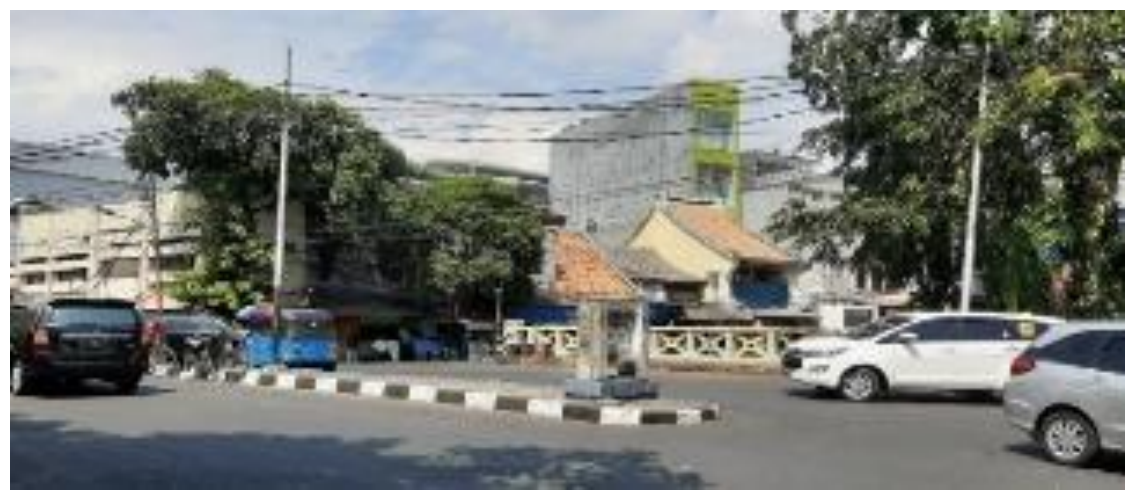

Gambar 10. Pertigaan Asemka Sumber: Penulis,2019

T2 - Pertigaan Asemka terletak menghubungi Jl. Pintu Kecil, Jl. Pancoran, dan Jl. Toko Tiga. Disini terletak tugu pemprov DKI yang berkesan menjadi seperti landmark antar 3 ruang berbeda (Glodok, Pancoran, Pasar Pagi). 
Tapak ditargetkan untuk menjadi third place yang dapat mewadahi aktivitas di sekitarnya terutama dari 3 pusat terbesar di sekitarnya yaitu C1-Pasar Pagi Asemka, C2-Pancoran Chinatown Point, dan C3-Stasiun Jakarta Kota. Didukung dengan aksesibilitas dari D4, D5, D6. Program yang berikutnya akan diajukan harus dapat merangkai kegiatan eksisting dari 3 pusat tersebut.

\section{Skema Desain}

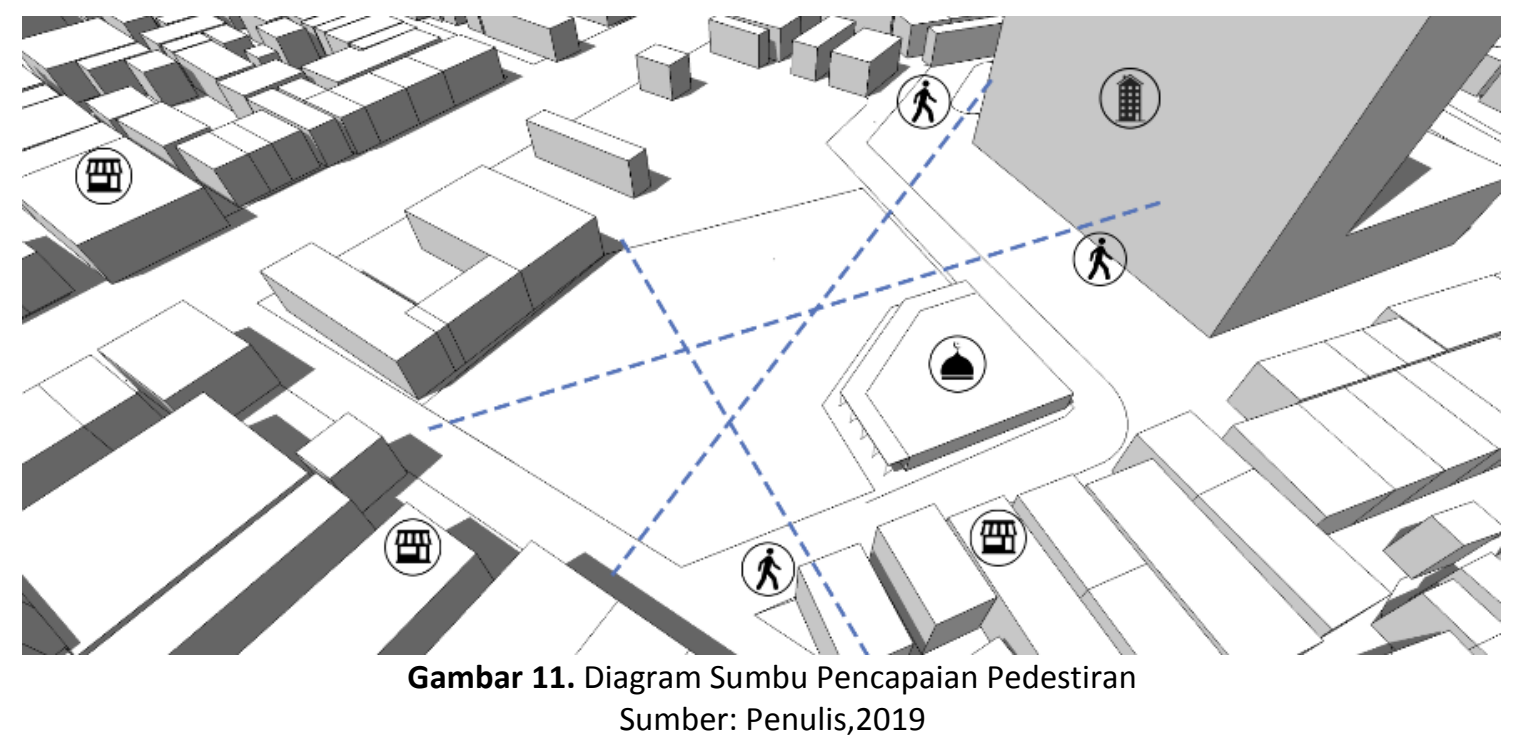

Langkah pertama yang diterapkan dalam perencanaan adalah pembagian zonasi ruang berdasarkan axis pencapaian pedestrian. Ketiga garis sumbu berasal dari; 1) pencapaian dari Jl. Gloria menuju tapak, 2) pencapaian dari Apartemen Pancoran Chinatown Point menuju tapak, 3) pencapaian dari Asemka menuju tapak.
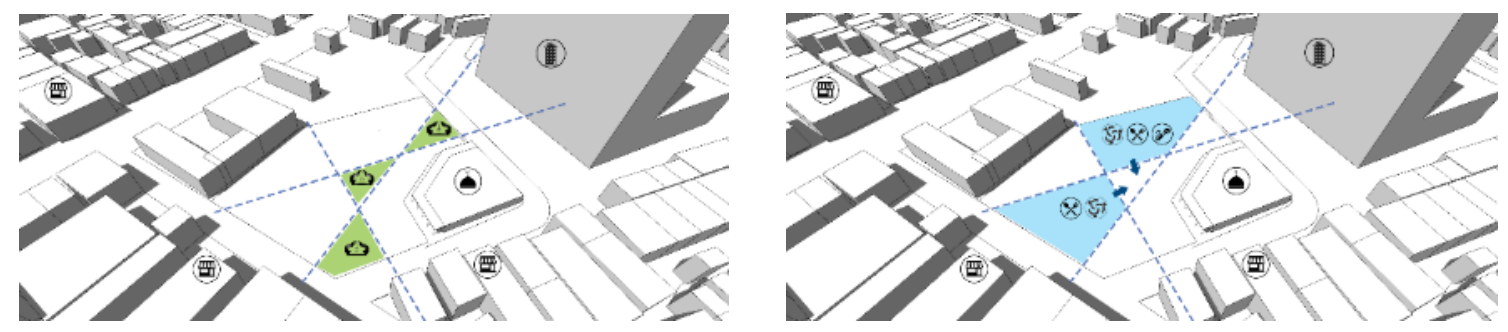

Gambar 12. Diagram Pembagian Zonasi Ruang Sumber: Penulis,2019

Setelah sumbu terdefinisi, dari perpotongan yang dianggap sebagai titik temu sirkulasi pengunjung, menghasilkan ruang publik/terbuka yang berfungsi sebagai common space. Dua ruang yang terbentuk bersebelahan dengan ruang publik menjadi ruang yang menunjang program utama. 

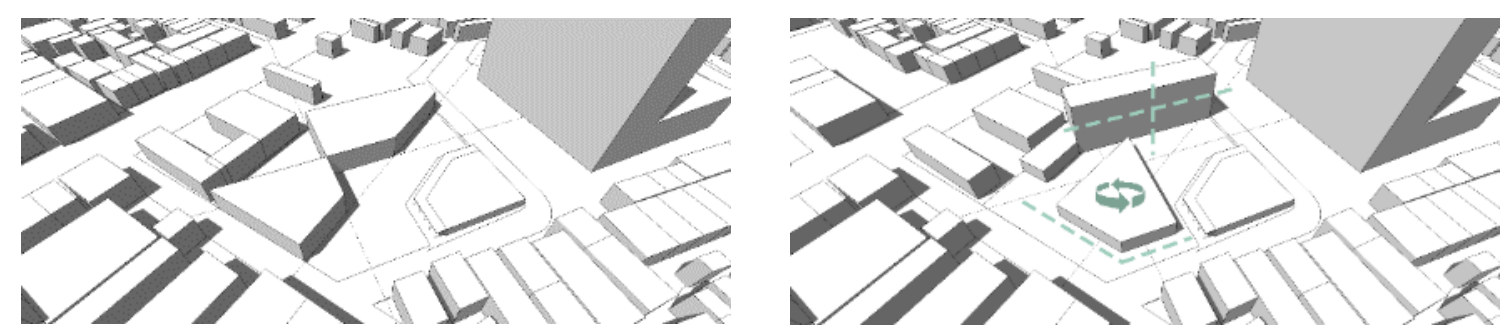

Gambar 13. Diagram Pembentukan dan Penyesuaian Massa Sumber: Penulis,2019

Dari hasil pembagian zonasi, ruang yang terbentuk diesktrusi menjadi sebuah massa yang kemudian disesuaikan dengan orientasi jalan dan bangunan sekitarnya.
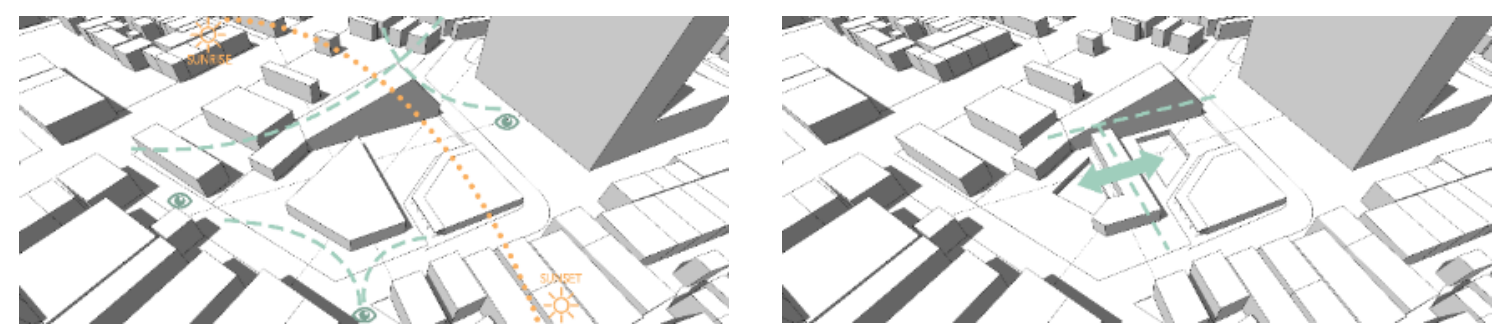

Gambar 14. Respon Massa terhadap Skyline dan Konektivitas Sumber: Penulis,2019

Merespon skyline dan sudut view dari pedestrian, massa program utama dibuat berbentuk segitiga untuk meramahkan view dari pejalan kaki serta menghindari terbentuknya alley karena berseberangan dengan gedung tinggi. Bentuk massa kemudian disesuaikan untuk menunjang konektivitas antar dua ruang publik.

\section{Programmatik}

Tempat Budaya Pinangsia memliki 4 program utama dan 2 program penunjang sebagai berikut;

1. Food Court (25\%): Terletak di lantai dasar dan menjadi salah satu program utama dimana individu maupun kelompok dapat sarapan, makan siang, dan makan malam sambil bercengkerama dan bermain (dine \& play).

2. Cultural Market (20\%): Terletak di lantai semi basement. Terdiri dari unit retail, plaza, dan amphitheater. Merupakan common space yang fleksibel untuk menunjang ragam aktivitas. Plaza dan amphitheater dapat disewakan untuk event tertentu dimana penghasilannya akan disalurkan untuk pengembangan komunitas Chinatown Art Culture.

3. Karaoke (25\%): Program utama yang mengangkat seni music. Terletak di lantai dua, dilengkapi dengan bar \& lounge dimana orang dapat bersantai dan membaca buku sebagai penunjang.

4. Cultural Workshop (12\%): Kegiatan workshop terbuka untuk umum, terutama untuk pengunjung yang berasal dari luar kawasan Pinangsia Glodok. Didukung oleh komunitas Chinatown Art Culture, dimana hasil-hasil workshop dipamerkan serta dijual di Cultural Market.

5. Breakout Area (3\%): Ruang untuk menikmati pemandangan matahari terbenam yang terletak di lantai paling atas.

6. Area Service (15\%): Program penunjang kebutuhan utilitas bangunan. 


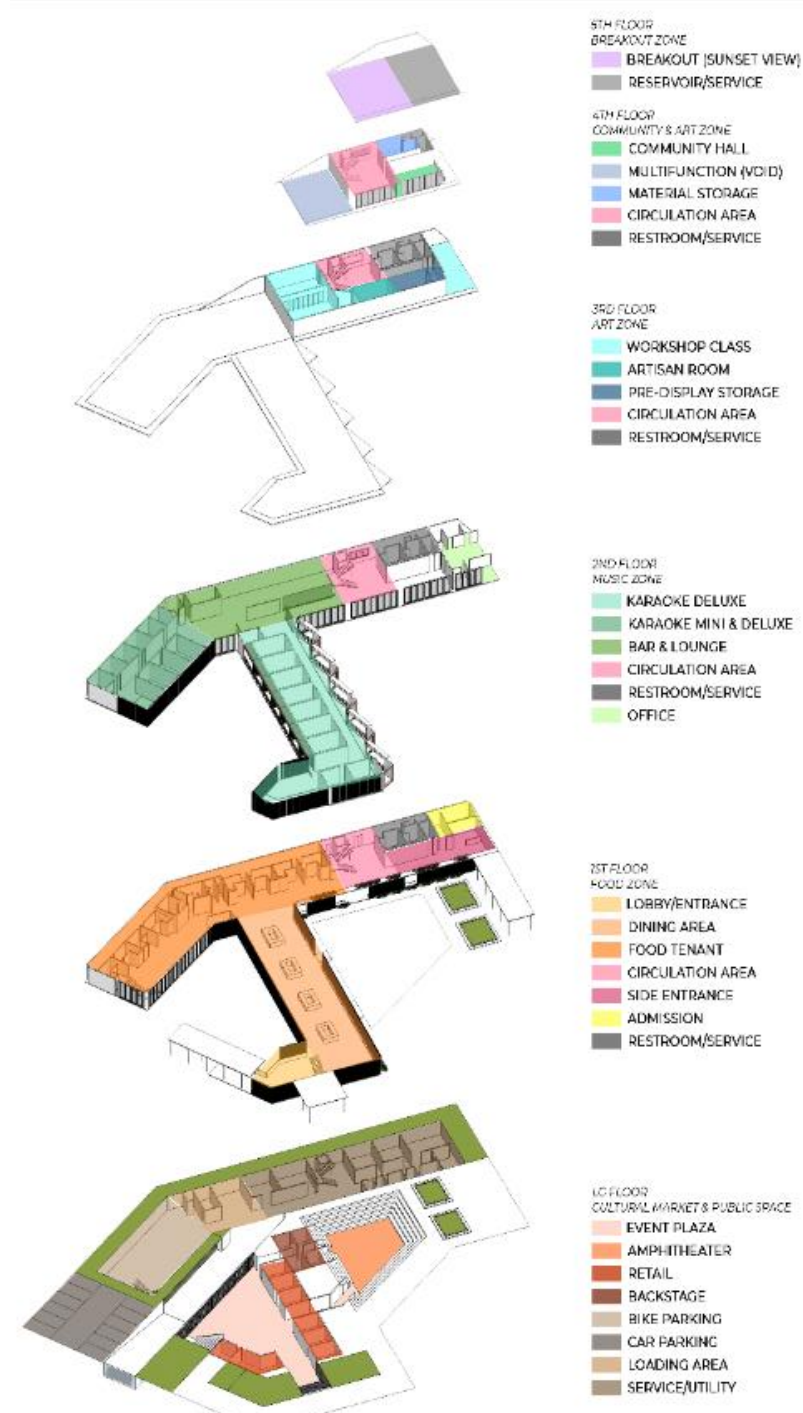

Gambar 15. Programmatic Exploded Plan Sumber: Penulis,2019

\section{Hasil Bentuk Rancangan}
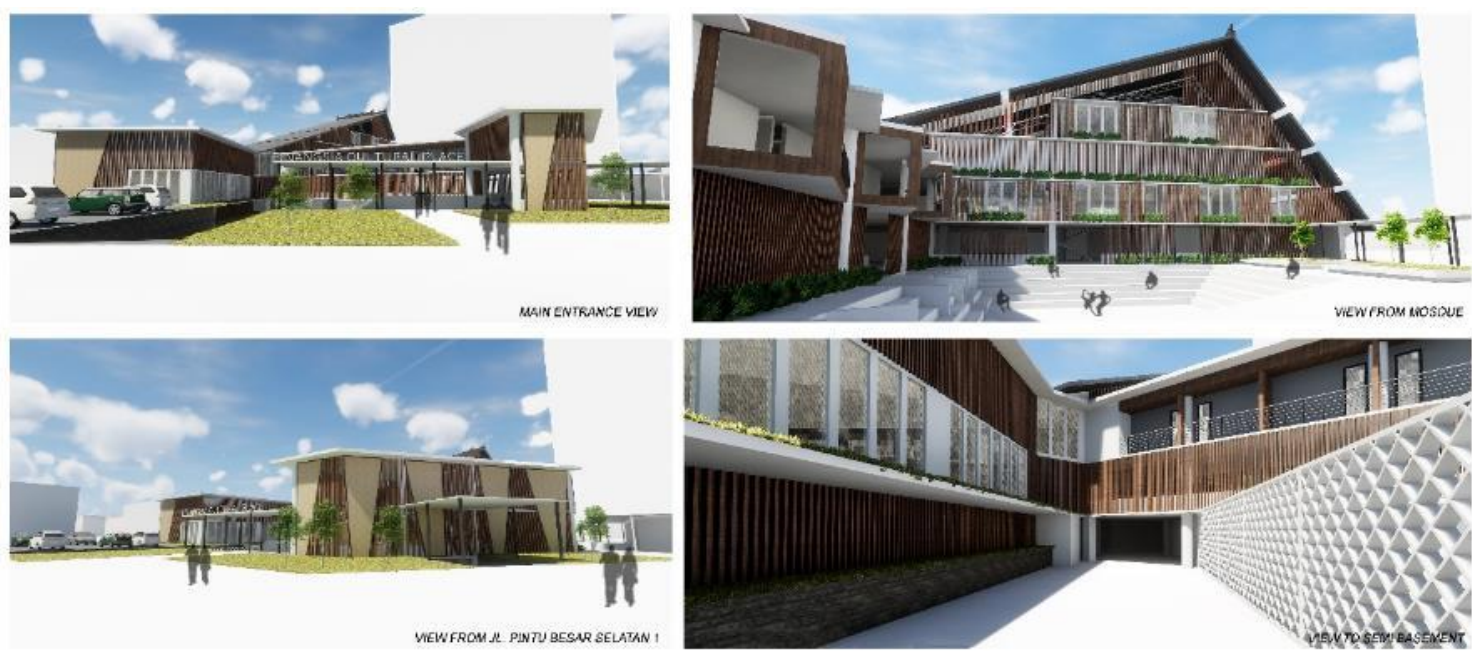

Gambar 17. Perspektif 3D

Sumber: Penulis,2019 


\section{Struktur dan Utilitas}

Bangunan menggunakan struktur beton dan baja bertulang untuk kolom, balok, dan plat lantai. Bentang terpendek 5 meter sedangkan bentang terpanjang adalah 8 meter. Kolom memiliki dimensi $50 \times 50 \mathrm{~cm}$ dan plat lantai setebal $14 \mathrm{~cm}$. Untuk rangka atap menggunakan struktur baja siku dengan penutup atap yaitu genteng metal pasir. Sambungan baja siku terhadap kolom menggunakan plat baja yang dibor dengan dynabolt tipe M12.
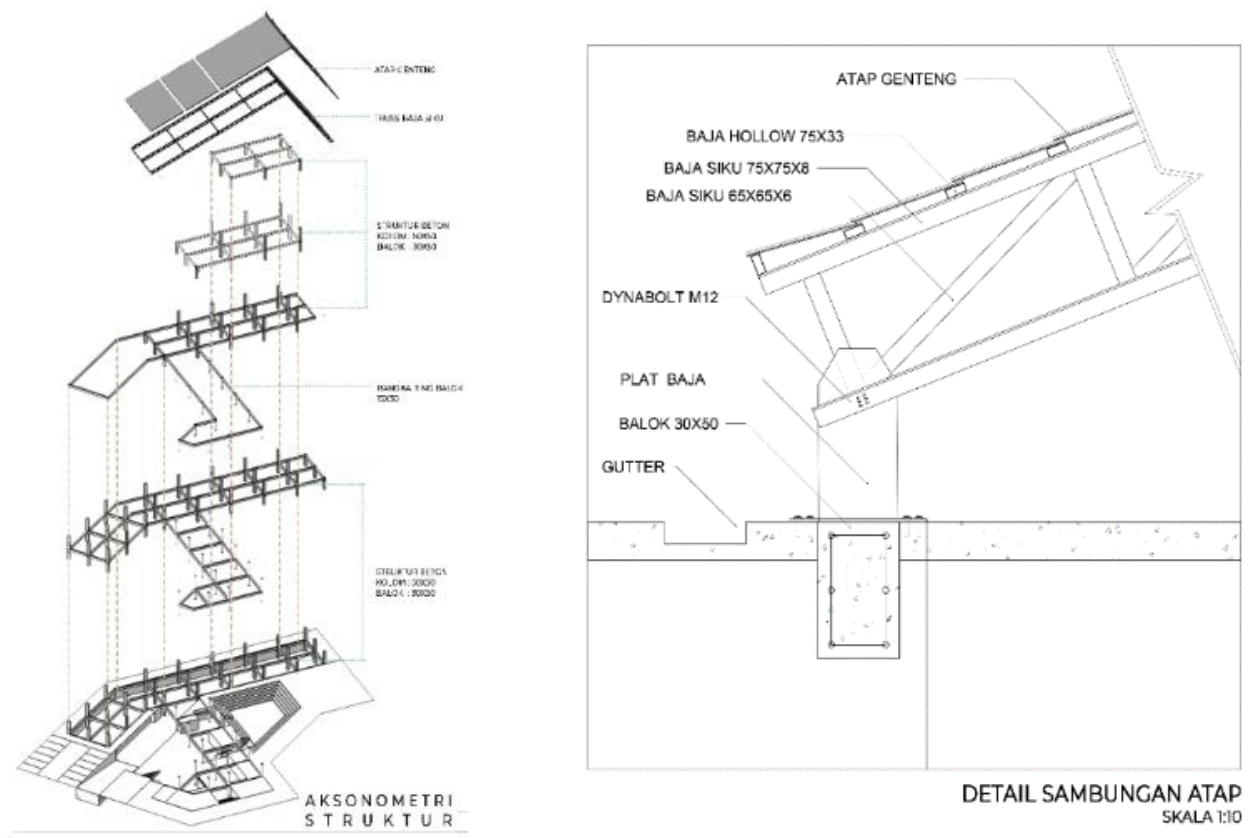

Gambar 18. Aksonometri dan Detail Struktur Sumber: Penulis,2019
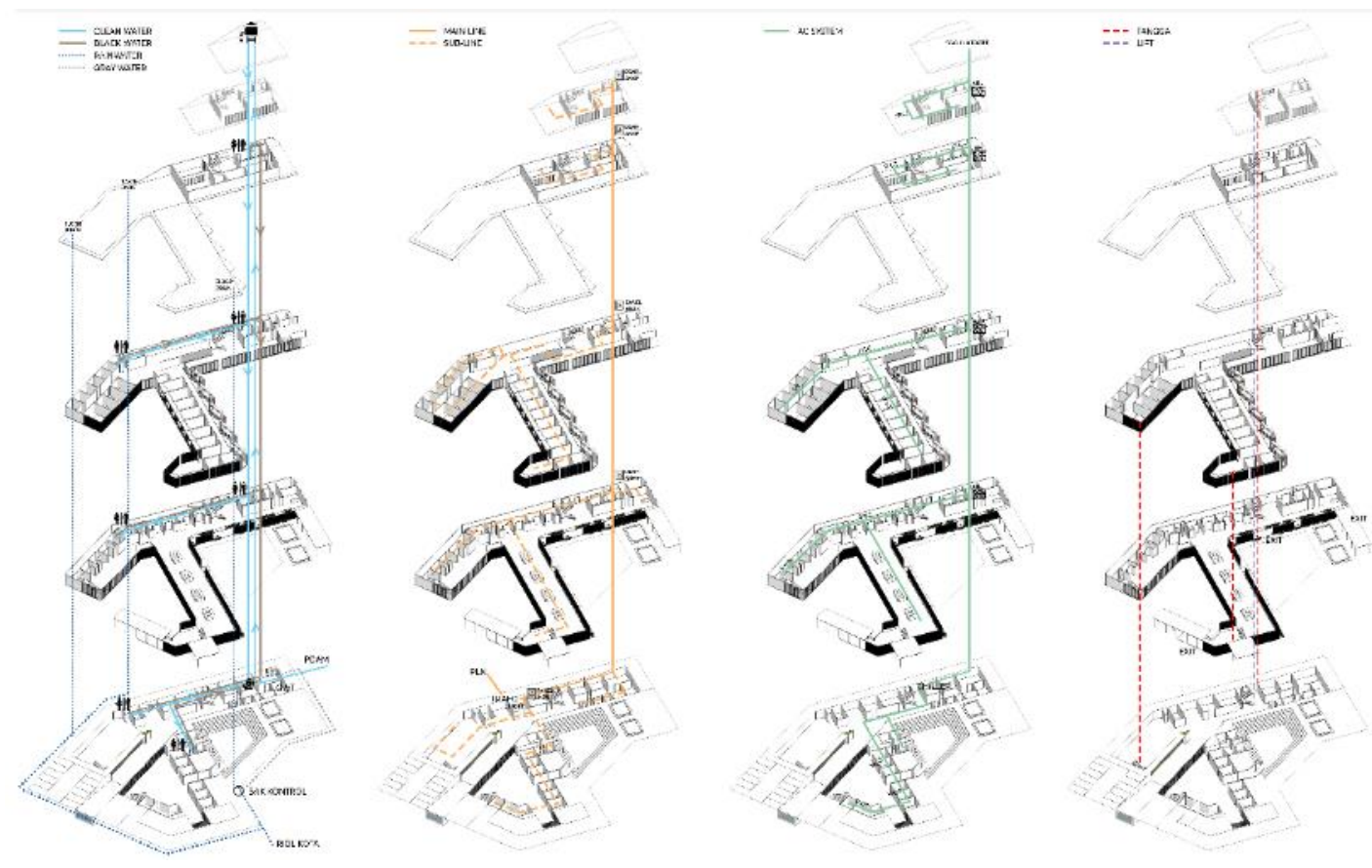

Gambar 19. Aksonometri Utilitas Sumber: Penulis,2019 


\section{KESIMPULAN DAN SARAN \\ Kesimpulan}

Kemajuan teknologi yang serba instan membuat masyarakat kurang berinteraksi langsung terhadap orang-orang di sekitarnya, sehingga melahirkan sikap yang anti-sosial dengan lingkungannya. Salah satu faktor yang dapat menjadi perantara untuk menghubungkan kembali komunitas adalah budaya. Budaya yang dimaksud adalah ragam aktivitas sehari-hari yang dilakukan secara terus menerus hingga menjadi karakter dari komunitas tersebut. Aktivitas ini berperan sebagai selingan atau hiburan untuk masyarakat di tengah tuntutan pekerjaan yang tinggi. Di kawasan Pinangsia, food and music menjadi hiburan utama bagi masyarakat di dalamnya. Didukung juga oleh kegiatan workshop budaya yang dapat menjaring kedatangan warga dari luar kawasan, Pinangsia Cultural Place berhasil menjadi wadah fisik untuk penyaluran aktivitas tersebut yang dapat meningkatkan interaksi sosial sekaligus melestarikan budaya lokal masyarakat.

\section{Saran}

Saran penulis alangkah lebih baik bila proyek ini bisa tetap hidup aktivitas di dalamnya dengan partisipasi keberlanjutan oleh komunitas dan masyarakat di Pinangsia Glodok. Komunitas Chinatown Art Culture harus dapat mempertahankan perannya dalam membawa masyarakat Pinangsia Glodok dalam suatu kebersamaan yang berlanjut.

\section{REFERENSI}

Bina Nusantara University. (2014, February). Perancangan Ruang Karaoke. Retrieved from Binus Library: https://library.binus.ac.id/eColls/eThesisdoc/Bab2/2014-2-00382DI\%20Bab2001.pdf

Crawford, M. (2008). Blurring The Boundaries: Public Space and Private Life. In J. L. Chase, Everyday Urbanism (pp. 22-35). New York: Monacelli Press.

Erwan. (2018, November 29). Komunitas China Town Art Culture, Penjaga Akulturasi Budaya di Glodok. Retrieved from Jakarta: https://terasjakarta.id/plugin/article/view/3083/komunitas-china-town-art-culturepenjaga-akulturasi-budaya-di-glodok

G.Mion, E. (2017, March 22). Dining Facilities. Retrieved from Whole Building Design Guide: A Program of The National Institute of Building Sciences: www.wbdg.org/buildingtypes/community-services/dining-facilities

Greenbaum, S. (2016, September 5). Plaza. Retrieved from Whole Building Design Guide: www.wbdg.org/space-types/plaza

Lang, J. (2005). Urban Design: A Typology of Procedures and Products. Oxford: Elsevier.

Madanipour, A. (1996). Design of Urban Space. Michigan: Wiley.

McLaren, D., \& Agyeman, J. (2015). Sharing Cities: A Case for Truly Smart and Sustainable Cities. Cambridge: The MIT Press.

National Institute of Building Sciences. (2017, April 4). Training Facility. Retrieved from Whole Building Design Guide: http://www.wbdg.org/building-types/education-facilities/trainingfacility

Oldenburg, R. (1989). The Great Good Place. Cambridge: Da Capo Press.

Powell, K. (2000). City Transformed: Urban Architecture at the Beginning of 21st Century. New York: te Neues Publishing Company.

Sudjawardi, V. Y. (2017). Standar Usaha Karaoke. Lampiran Peraturan Menteri Pariwisata dan Ekonomi Kreatif Republik Indonesia Nomor 16 Tahun 2014 Tentang Standar Usaha Karaoke, 1-5.

Tjahjono, G. (2000). Metode Perancangan: Suatu Pengantar Untuk Arsitek dan Perancang. Depok: Universitas Indonesia . 
Utama, W. S. (2007). Kehidupan Sosial-Budaya Masyarakat Tionghoa di Batavia 1900an1930an. Yogyakarta: Jurusan IImu Sejarah UGM.

Zamfir, M. (2015). A Brief Introduction to Community Architecture Concept: From Believing to Reality. Re[search] Through Architecture, 1-11. 